Цінь Бовен аспірант кафедри соціальної реабілітації та соціальної педагогіки факультету психології Київського національний Університету імені Тараса Шевченка, вул. Володимирська, 60, Київ, 01033, тел.: (063) 64846-85, e-mail: qinbowen0@ gmail.com, https://orcid.org/0000-0003-3909-0990

\title{
ПСИХОЛОГІЧНИЙ АСПЕКТ СОЩІАЛІЗАЦІЇ ОСОБИСТОСТІ В ОСВІТНЬОМУ СЕРЕДОВИЩІ УНІВЕРСИТЕТУ
}

Анотація. Зміна суспільних відносин в Україні характеризується увагою до економічних та політичних аспектів функціонування держави. В центрі уваги наразі серед багатьох суспільних викликів залишається соціалізація особистості, зокрема, в освітньому середовищі закладів освіти. Не стали винятком і питання удосконалення особистості, іiі творчого розвитку, активності, загальної і професійної підготовки, залучення до соціального буття. Означені питання пов'язані 3 процесом соціалізації молоді, особливо студентської. Соціалізацію особистості визначено як тривалий, багатокомпонентний процес, в основу якого лягає система соціальних і моральних цінностей, власні ідеали, норми i правила поведінки особистості. Результатом досліджуваного феномену виокремлено сприйняття i засвоєння особистістю всіх структурних складових системи соціалізації. З'ясовано, що процес соціалізації особистості має різноманітні процеси, які відбуваються у житті особистості. Результат процесу соціалізації не завжди передбачуваний і не завжди відповідає інтересам суспільства. Метою статі $є$ виокремлення психологічного аспекту у процесі соціалізації особистості в освітньому середовищі університету.

Наголошено на тому, що більшість науковців досліджують процес соціалізації особистості як показник рівня іiї адаптації, проявом якого є не лише пристосування особистості до певних життєвих і професійних умов, а й спрямування на їх зміну. Ступінь зміни цих умов $€$ показником сутності соціалізації особистості.

Описано освітнє середовище університету як інституту соціалізації з різносторонніми соціальними зв'язками, що забезпечують цілісність взаємодії особи і суспільства. Виокремлено психологічні аспекти соціалізації особистості в освітньому середовищі університету. Зроблено висновок про те, що соціальна адаптація в освітньому середовищі університету $\epsilon$ складним, багатоаспектним, динамічним процесом. Досліджуване явище вимагає синергетичного підходу до дослідження проблеми, поєднання зусиль соціології, філософії, психології, педагогіки, соціальної педагогіки тощо. 
Ключові слова: соціалізація особистості, соціальні інститути, розвиток особистості, інтеріоризація особистості.

Qin Bowen PhD student of the Social Rehabilitation and Social Pedagogy Department Faculty of Psychology Taras Shevchenko National University of Kyiv, Volodymyrska St., 60, Kyiv, 01033, tel.: (063) 648-46-85, e-mail: qinbowen0@gmail.com, https://orcid.org/0000-0003-3909-0990

\section{PSYCHOLOGICAL COMPONENT OF PERSONALITY SOCIALIZATION IN THE UNIVERSITY EDUCATIONAL ENVIRONMENT}

Abstract. The change in public relations in Ukraine is characterized by attention to the economic and political aspects of the functioning of the state. Currently, the focus among many social challenges remains the socialization of the individual, in particular, in the educational environment of educational institutions. The issues of personal improvement, its creative development, activity, general and professional training, involvement in social life were no exception. These issues are related to the process of socialization of young people, especially students. The socialization of the individual is defined as a long, multi-component process, which is based on a system of social and moral values, their own ideals, norms and rules of behavior of the individual. The result of the studied phenomenon highlights the perception and assimilation of all the structural components of the socialization system. It was found that the process of socialization of the individual has a variety of processes that occur in the life of the individual. The result of the socialization process is not always predictable and does not always meet the interests of society. The purpose of the article is to highlight the psychological aspect in the process of socialization of the individual in the educational environment of the university.

It is emphasized that most scientists study the process of socialization of the individual as an indicator of the level of its adaptation, a manifestation of which is not only the adaptation of the individual to certain living and professional conditions, but also the direction to change them. The degree of change in these conditions is an indicator of the essence of socialization of the individual.

The educational environment of the university is described as an institution of socialization with multifaceted social ties that ensure the integrity of the interaction of the individual and society. The psychological aspects of personality socialization in the educational environment of the university are singled out. It is concluded that social adaptation in the educational environment of the university is a complex, multifaceted, dynamic process. The studied phenomenon requires a synergetic approach to the study of the problem, a combination of efforts of sociology, philosophy, psychology, pedagogy, social pedagogy and more.

Keywords: socialization of personality, social institutions, development of personality, internalization of personality.

Постановка проблеми. Сучасні тенденції у світі актуалізують питання адаптації людини до різноманітних просторів у багатонаціональному 
середовищі. Незаперечно важливою для науки, теорії і практики наразі $\epsilon$ соціальна адаптація іноземних студентів в освітньому середовищі університету, що є важливою складовою процесу соціалізації особистості вцілому.

В умовах відкритості кордонів, міжнародної співпраці особливої значущості набуває відповідальна місія освітнього середовища університету, усвідомлення важливої ролі студентів, зокрема, іноземних студентів у трансформації кроскультурного суспільства та необхідність мобільно реагувати на зміни в ньому. Варто зважити на те, що процес адаптації студентів має нести цільове спрямування, комплексність, систематичність та цілісність під час загального процесу адаптації у міжнародній спільності. Соціальна адаптація іноземних студентів в освітньому середовищі університету враховує особливості, такі як: соціокультурні, соціопсихологічні, етнопсихологічні тощо. Соціально адаптований студент здатний самостійно працювати над власним розвитком, підвищенням освітнього й культурного рівнів; розвивати вміння самостійно набувати необхідних для професійної діяльності компетенцій; адаптуватись та інтегруватись у багатонаціональному і полікультурному середовищі.

Проблему соціальної адаптації іноземних студентів в освітньому середовищі університету регламентовано нормативно-правовою базою 3 питань перебування та навчання іноземців в Україні: Закон України «Про вищу освіту» (2019р.); Наказ МОН № 1272 «Порядок видачі іноземцям та особам без громадянства запрошень на навчання (стажування) в Україні та їх реєстрації. Порядок організації набору та навчання (стажування) іноземців та осіб без громадянства» (2015р.); Наказ МОН № 1378 «Умови прийому на навчання до вищих навчальних закладів України в 2018 році» (2017 р.); Наказ МOH № 504 «Деякі питання визнання в Україні іноземних документів про освіту» (2015 р.); Наказ МОН № 220 «Про затвердження Порядку проставлення в МОН України апостиля на офіційних документах, виданих навчальними закладам, державними органами, підприємствами, установами i організаціями, що стосуються сфери освіти і науки» (2009 р.) тощо.

Аналіз останніх досліджень і публікацій. Аналіз наукової літератури надав можливість виявити різні організаційно-змістові способи адаптації тудентів до освітнього середовища закладів вищої освіти, розроблені науковцями: Г. Алєєвою, О. Білоус, І. Гребенніковою, О. Кравцовим, I. Мушараповою, Д. Порох , С. Шестополовою, на основі яких, базуючись на комплексному підході, було виокремлено умови успішної адаптації іноземних студентів до освітнього середовища університетів України, які характеризуються як сукупність створених у освітньому процесі провідних обставин, що забезпечують ефективність процесу адаптації іноземної молоді до культурно-освітнього середовища університетів України.

Мета статті - виокремлення психологічного аспекту у процесі соціалізації особистості в освітньому середовищі університету.

Виклад основного матеріалу. У сучасному суспільстві молодий фахівець стикається 3 проблемою самовизначення, що безпосередньо 
пов'язано 3 питанням його професійного вибору. Аналізуючи наукову літературу, можна дійти до висновку, що свідомо обираючи професію, майбутній фахівець розраховує на власні знання про себе. Сучасна криза професій дає змогу констатувати, що знань про власне «Я»є недостатньо для успішного професійного розвитку. Відтак, визнання даної проблеми та пошук шляху для іiі успішного вирішення $\epsilon$ важливим вектором формування успішного професіонала.

На фоні дослідження власного «Я» слід виокремити місце соціалізації майбутніх фахівців. У сучасному соціумі, зокрема, у його психологічному сегменті, усвідомлення власної ролі у суспільстві $\epsilon$ досить важливим. Зазначений процес передбачає: гнучке адаптування до змін як у соціальній, так і в професійній сфері; самостійну роботу над власним розвитком (напрямом і змістом професійної діяльності); підвищення освітнього й культурного рівнів; швидку адаптацію та інтегрування у сучасний багатонаціональний і полікультурний соціум.

Досліджуючи концепцію власного «Я», слід відмітити процес інтеріоризаціï (лат. interior — внутрішній) - процес формування внутрішньої структури людської психіки за допомогою засвоєння соціальних норм, цінностей, ідеалів, процес переведення елементів зовнішнього середовища у внутрішнє «Я» [1].

Джерела сучасної концепції соціалізації містяться у працях американського психолога Альберта Бандури, французького соціолога i юриста Габріеля Тарда, американського соціолога Толкотта Парсонса. Нині процес соціалізації наука розглядає в широкому і вузькому розумінні цього поняття. Соціалізація у широкому розумінні - це визначення походження i формування родової природи людини (йдеться про філогенез - історичний процес розвитку людства), у вузькому - процес включення людини в соціальне життя шляхом активного засвоєння нею норм, цінностей та ідеалів. 3 урахуванням цього соціалізацію можна розглядати як типовий та одиничний процеси. Типовий процес визначається соціальними умовами, залежить від класових, етнічних, культурних та інших відмінностей. Пов'язаний він із формуванням типових для певної спільноти стереотипів поведінки. Соціалізація як одиничний процес пов'язана 3 індивідуалізацією особистості, виробленням нею власної лінії поведінки, набуттям життєвого досвіду, становленням індивідуальності.

Слушною є позиція Г. Тарда, який у своїй роботі виокремив те, що основним механізмом соціалізації $\epsilon$ наслідування, що регулюється суспільством через систему освіти, зокрема навчання і виховання, сім'ю, громадську думку та інші соціальні інститути. На думку вченого, основною метою освіти $є$ виховання i створення умов для розвитку творчої особистості [2].

Двосторонній процес соціалізації передбачає засвоєння індивідом соціального досвіду шляхом входження у соціум, систему соціальних зв'язків i активне їх відтворення. Тобто людина не тільки адаптується до умов соціуму, елементів культури, норм, що формуються на різних рівнях 
життєдіяльності суспільства, а й завдяки своїй активності перетворює їх на власні цінності, орієнтації, установки.

Незаперечним є те, що соціалізація у професійній підготовці майбутніх фахівців є складним і постійним процесом формування системи соціальних відносин. Відповідно, система соціалізації має складну структуру i розташована на всіх етапах професійної підготовки по-різному. А відтак, соціалізація вказує на пристосування індивіда до рольових функцій, соціальних норм, спільностей, до умов функціонування різних сфер суспільства.

Стосовно професійної підготовки майбутніх фахівців слід виокремити дослідження соціалізації 3 точок зору психології. Психологічна наука досліджує цікаве нам явище як процес занурення особистості в суспільство, ліквідуванням неприємностей та пошуком задоволення у способі власної реалізації; як результат зміни та створення нового життєвого простору (К. Левін); як шлях морального становлення особистості 3 урахуванням моральних канонів соціуму [3].

Досліджуючи соціалізацію особистості, слід виокремити іiі міждисциплінарний аспект. Філософія розглядає досліджуваний нами процес як необхідне явище i умову виконання людиною свого призначення як індивіда, особистості та індивідуальності шляхом взаємодії у системі відносин 3 іншими людьми. Особливістю даного процесу, 3 точки зору філософії, є те, що на соціалізацію впливають особистісні якості кожної особистості.

У контексті соціології соціалізація людини розглядається 3 двох боків: як процес адаптації особистості до суспільства під впливом його інститутів i як процес, детермінований «діалогом активностей» особистостей, їх внутрішніми потребами, якостями, цінностями.

Психологія пов'язує процес соціалізації 3 постійним розвитком особистості в усіх його проявах. Але все ж таки, можемо виокремити спільні i відмінні риси вищезазначених феноменів. Зальною рисою $є$ те, що i соціалізація, і розвиток особистості зумовлені зовнішніми чинниками. А відтак, відмінним стає те, що саме розвиток покладається на внутрішню рушійну силу особистості (наявність певних внутрішніх, зокрема, психологічних суперечностей, що виникають через появу невідповідності потреб і можливостей, очікуваного і отримуваного, бажаного і реального тощо).

Доцільною $\epsilon$ позиція, що дефініції «соціалізація» i «розвиток» не $\epsilon$ антонімами, i не є синонімами. Тому можемо констатувати, що розвиток $\mathrm{i}$ соціалізація особистості $є$ взаємодоповнюючими елементами у становленні особистості. Саме психологічні особливості розвитку обумовлюють процес вибірковості особистості до різних взаємодій з оточенням.

Виокремимо, що соціалізація людини розгортається в конкретних умовах життєдіяльності. Цей процес охоплює всі аспекти залучення особистості до культури, навчання i виховання, за допомогою яких вона набуває соціальності, спроможності брати участь у соціальному житті. 
Успішній соціалізації сприяють такі чинники, як зміна поведінки, очікування і прагнення відповідати їм. У процесі історичної практики індивід виявляє свою соціальну сутність, формує соціальні якості, набуває особистого життєвого досвіду. Об'єктивно, формуючи та розвиваючи власне «Я», особа не може існувати без спілкування та поза діяльністю.

Враховуючи вищеозначене, необхідно виокремити основні ознаки, за допомогою яких визначають стадії соціалізації (рис.1), зокрема, залучення особистості до діяльності (отримання досвіду та опанування способами його відтворення); рівень розвитку самосвідомості людини; провідні інститути соціалізації, що здійснюють домінуючий вплив на процес становлення та розвитку особистості на цій стадії; способи соціалізації (опосередковані провідною діяльністю особистості); соціально-психологічні механізми соціалізації (соціум здійснює вплив на особистість через різноманітні інститути соціалізаціі).

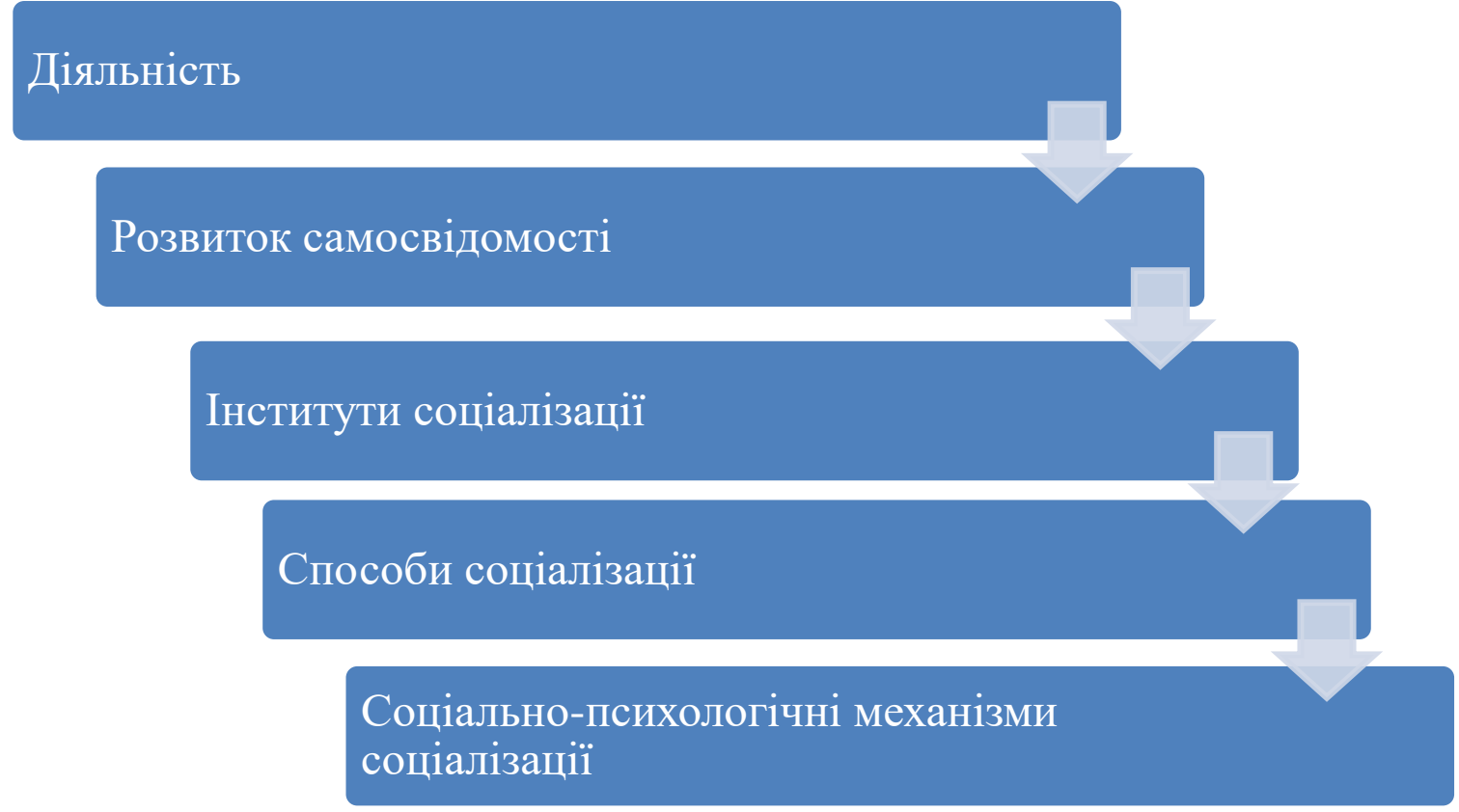

\section{Puc. 1. Стадї соціалізації особистості}

Джерело: розроблено автором

Із психологічної точки зору, сенс процесу соціалізації полягає у розвитку соціального досвіду особистості у процесі власної взаємодії 3 найближчим оточенням. Розвиток такого соціального досвіду характеризується стійкою формою організації спільної діяльності, усталеним комплексом правил, принципів, норм, що ії регулюють.

Процес соціалізації не можливий без залучення громадськості. Залучення громадськості потрібне не тільки для оцінки потреб громади, а й для погодження стратегії розв'язання проблем. Наприклад, проблему безробіття у місцевій громаді можна вирішувати різними шляхами - через перекваліфікацію кадрів, відновлення закритого виробництва, сприяння становленню власного бізнесу тощо. Проте, хоч якою була б стратегія, вона має бути здійсненною та прийнятною, зокрема, для представників місцевих 
виборчих органів влади [5].

Відзначимо, що особливе місце тут займає роль діючих у соціумі інститутів соціалізації 3 різносторонніми соціальними зв'язками, що забезпечують цілісність взаємодії особи і суспільства; заданим набором доцільно орієнтованих стандартів поведінки особи в конкретних ситуаціях (Інститути соціалізації - конкретні групи, в яких людина долучається до системи норм, цінностей і соціальних зв'язків (сім'я, школа, неформальні організації, засоби масової Інформації тощо)).

Враховуючи, що ще одним наскрізним поняттям у даному досліджені $є$ освітнє середовище університету, то варто розглянути соціалізацію крізь призму професійної освіти. За науковцем І. Сидоренко, професійну соціалізацію слід розглядати як багатоплановий, суперечливий процес занурення особистості у професійну освіту. Вчений наголошує, що даний етап потрібен для наступного етапу: входження в трудовий арсенал країни [4].

Зазначимо, що освітнє середовище університету є одним 3 інститутів соціалізації, які були створені у сучасному суспільстві. Саме означений соціальний інститут дає змогу оволодіти навичками, які включають опанування іншомовною, соціокультурною, психологічною і професійною термінологією.

Виокремимо, якщо соціалізація $є$ ознакою освітнього середовища університету, то відповідно до підготовка до цього процесу є незаперечною частиною професійної підготовки майбутніх фахівців.

А відтак, вважаємо за необхідне охарактеризувати особистість, процес соціалізації якої відбувається в освітньому середовищі університету. Соціалізована особистість постане перед соціумом як: ерудований виконавець, професіонал; особистість 3 активною життєвою позицією; особистість динамічна у власних потребах та професійних інтересах; особистість, яка здатна до творчого вирішення проблем різної складності; активатор наукового й соціального прогресу; особистість, яка здатна сприймати конкурентність як належний спосіб отримання роботи та підтвердження свого професійного рівня, а не як жорстокий спосіб контролю; особистість з високим рівнем адаптаційних можливостей.

Освітнє середовище університету створює можливості для ефективного використання процесу соціалізації через діяльність у різних сферах, приймання виваженних рішень та застосування рефлексії. Психологічний аспект соціалізації особистості - це своєрідна готовність до продовження освіти і готовність до самовдосконалення, розвитку професійних інтересів та професійно важливих якостей; уточнення подальшої професійної і життєвої перспективи. Як результат даного процесу - це формування конкурентоспроможного на ринку праці кваліфікованого робітника, фахівця, готового до активної професійної діяльності і переорієнтації з однієї професії на іншу.

Висновок. Соціалізація особистості в освітньому середовищі університету є складним, багатоаспектним, динамічним процесом. Означене 
вимагає синергетичного підходу до дослідження проблеми, поєднання зусиль соціології, філософії, психології, педагогіки, соціальної педагогіки тощо. Важливим є питання розробки і реалізації механізмів соціальної адаптації особистості в освітньому середовищі університету. Усвідомлюючи багатогранність проблеми доцільним $є$ зосередження уваги на основних аспектах досліджуваної проблеми, визначення організаційно-змістових умов, моделювання процесу соціалізації особистості в освітньому середовищі університету.

\section{Лimepamypa:}

1. Радул В. В. Особливості професійної соціалізації особистості педагога / В. В. Радул // Науковий вісник Миколаӥвського ДУ імені В. О. Сухомлинського, 2011. Випуск 1.33. Сер. Педагогічні науки . С. 66-70.

2. Тард Г. Социальные этюды / Габриель Тард. СПб., 1902. С. VI-XI.

3. Diachok, N., Chernukha, N., Tokaruk, L., Udovenko, I., Petrova, M. Practical-Oriented Concept as a Principle of Professional Education of the Future Professionals. International Journal of Higher Education, 2020. Vol 9, No 4. P. 272-282

4. Сидоренко I. В. Психолого-педагогічні знання як фактор професійної соціалізації майбутніх фахівців у системі вищої освіти [Електронний ресурс] // Режим доступу: http://www.nbuv.gov.ua./portal/Sos_Gum/Npchdu/Pedagogics/ Випуск 4, 2012

5. Савченко С. В. Науково-теоретичні засади соціалізації студентської молоді в поза навчальній діяльності в умовах регіонального освітнього простору : Автореферат дис. ... докт. пед. наук: 13.00.05 / С. В. Савченко // Луганський нац. пед. ун-т ім. Т. Шевченка. Л., 2004. $42 \mathrm{c}$.

6. Семигіна Т. В. Модель соціального планування на місцевому рівні. Наукові записки. Педагогічні, психологічні науки та соціальна робота, 2007. Том 59. С. 61-66.

7. Шулигіна Р. А. Особливості професійної соціалізації студентської молоді в освітньому просторі ВНЗ [Електронний ресурс] // Режим доступу: http://www.ird.npu.edu.ua/files/shulygina.pdf

\section{References:}

1. Radul, V. V. (2011). Osoblyvosti profesiinoi sotsializatsii osobystosti pedahoha [Features of professional socialization of the teacher's personality]. Naukovyi visnyk Mykolaivskoho DU imeni V. O. Sukhomlynskoho - Scientific Bulletin of the V. O Sukhomlinsky Nikolaev State University, Vypusk 1.33, 66-70 [in Ukrainian].

2. Tard, H. (1902). Sotsyalnble эtiudbl [Social sketches]. (Vols. 6-9). SPb [in Russian].

3. Diachok, N., Chernukha, N., Tokaruk, L., Udovenko, I., \& Petrova, M. (2020). Practical-Oriented Concept as a Principle of Professional Education of the Future Professionals. International Journal of Higher Education, Vol 9, No 4, 272-282 [in English].

4. Sydorenko, I. V. (2012). Psykholoho-pedahohichni znannia yak faktor profesiinoi sotsializatsii maibutnikh fakhivtsiv u systemi vyshchoi osvity [Psychological and pedagogical knowledge as a factor of professional socialization of future professionals in the system of higher education]. Scientific works, 46, 112-116. Retrieved from http://www.nbuv.gov.ua./portal/Sos_ Gum/ Npchdu/Pedagogics/ [in Ukrainian].

5. Savchenko, S. V. (2004). Naukovo-teoretychni zasady sotsializatsii studentskoi molodi $\mathrm{v}$ poza navchalnii diialnosti $\mathrm{v}$ umovakh rehionalnoho osvitnoho prostoru [Scientific and theoretical principles of socialization of student youth in extracurricular activities in the regional educational space]. Extended abstract of candidate's thesis. L. [in Ukrainian]. 
6. Semyhina, T. V. (2007). Model sotsialnoho planuvannia na mistsevomu rivni [Model of social planning at the local level. Scientific notes]. Naukovi zapysky. Pedahohichni, psykholohichni nauky ta sotsialna robota - Proceedings. Pedagogical, psychological sciences and social work, 2007, 59, 61-66 [in Ukrainian].

7. Shuligina, R. A. Features of professional socialization of student youth in the educational space of the university. Retrieved from https://ird.npu.edu.ua/files/shulygina.pdf [in Ukrainian]. 